\title{
Pola Sensitifitas Bakteri dan Penggunaan Antibiotik
}

\author{
Sri Sulastri Katarnida, Mulya Rahma Karyanti, Dewi Murniati Oman, Yusticia Katar \\ SMF Anak RS Penyakit Infeksi Sulianti Saroso, Jakarta
}

\begin{abstract}
Latar belakang. Penggunaan antibiotik yang tidak tepat bisa mengakibatkan resistensi obat, meningkatkan morbiditas, mortalitas dan biaya pengobatan. Faktor utama menentukan tepatnya penggunaan antibiotik adalah pemilihan antibiotik yang tepat, berdasarkan bakteri penyebab dan sensitifitasnya terhadap antibiotik. Sampai saat ini penelitian penggunaan antibiotik dan pola sensitifitas bakteri pada pasien anak di RS Penyakit Infeksi Sulianti Saroso belum pernah dilakukan.

Tujuan. Mengetahui pola bakteri dan sensitifitasnya terhadap antibiotik pada pasien anak yang dirawat di RSPI SS.

Metode. Penelitian dilakukan secara deskriptif, retrospektif dari rekam medis pasien rawat inap anak nonbedah, umur 1 bulan-15 tahun, dan hasil kultur tumbuh bakteri, periode tahun 2010 dan 2011. Pasien PICU dan pasien yang dalam perawatannya didiagnosis sebagai pasien bedah dikeluarkan dari penelitian. Hasil. Kultur dilakukan pada 286/1256 (22,8\%) sampel, tumbuh bakteri pada 96/286(33,6\%). Kelompok bayi 1bulan-<1 tahun $14(26,9 \%)$ paling banyak dilakukan kultur. Hasil kultur terbanyak S. typhi 11/54 (20,4\%), E. coli $9 / 54$ (16,7\%) dan S epidermidis 7 (13\%). S. typhi sensitif $100 \%$ terhadap sefotaksim, seftriakson, kloramfenikol, dan kotrimoksazol. Sensitifitas E. coli 62,5\% terhadap kloramfenikol, tetapi kurang sensitif terhadap antibiotik lainnya.

Kesimpulan. Bakteri terbanyak ditemukan $S$ typhi (20.4\%) dan E coli (16.7\%). Sensitifitas S typhi 100\% terhadap semua antibiotik yang digunakan (kotrimoksazol, tiamfenikol, kloramfenikol, sefotaksim dan seftriakson). Penggunaan antibiotik untuk $S$ typhi masih bisa dengan lini pertama antibiotik sejauh tidak ada kontra indikasinya. Sari Pediatri 2013;15(2):122-6.
\end{abstract}

Kata kunci: antibiotik, anak, kultur, sensititas

\footnotetext{
Alamat korespondensi:

Dr. Sri Sulastri Katarnida, Sp.A. SMF Anak RSPI. Prof. Dr. Sulianti Saroso, Jl. Sunter Permai Raya, Sunter 14340 Jakarta Utara. HP 0811864097, Fax 021.4718778 Tel 021.4895279,E-mail: srilastri07@ yahoo.co.id
}

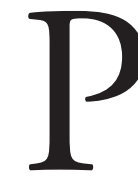

enggunaan antibiotik dengan justifikasi yang kurang tepat dapat mengakibatkan resistensi obat, meningkatkan morbiditas, mortalitas dan biaya pengobatan. ${ }^{1,2}$ Pilihan 
penggunaan antibiotik yang tepat hanya dapat dilakukan jika mengetahui bakteri penyebab yang paling memungkinkan dan pola sensitifitas yang berlaku. ${ }^{3}$ Dengan mengetahui pola bakteri pada kultur dan sensitifitasnya terhadap antibiotik maka pemilihan terapi empirik dapat ditentukan.

Pengidentifikasian bakteri patogen penyebab infeksi perlu dilakukan, kultur diikuti dengan uji kepekaan (sensitifitas) terhadap antibiotik. Waktu yang diperlukan untuk melakukan kultur dari bakteri tumbuh sampai uji sensitifitas, umumnya membutuhkan waktu 3 sampai 7 hari. Hal tersebut menyulitkan pemberian terapi definitif, terutama pada pasien yang mengalami infeksi berat yang harus mendapatkan antibiotik secepatnya. Apabila dari hasil uji sensitifitas ternyata pilihan antibiotik semula tadi tepat, serta gejala klinik jelas membaik maka terapi penggunaan antibiotik tersebut dapat diteruskan. Namun, jika hasil uji sensitifitas menunjukkan ada antibiotik lain yang lebih efektif, sedangkan dengan antibiotik semula gejala klinik penyakit tersebut menunjukkan perbaikan maka antibiotik semula tersebut sebaiknya diteruskan.

Namun, apabila hasil perbaikan klinis kurang baik, antibiotik yang diberikan semula dapat diganti dengan yang lebih tepat sesuai dengan hasil uji sensitifitas. ${ }^{4}$ Antibiotik pada sarana kesehatan digunakan secara empirik, profilaksis, atau secara definitif. Kualitas dari terapi empirik dan terapi profilaksis sebagian besar ditentukan oleh ketersediaan dari data surveillance lokal terhadap resistensi antibiotik dan dari informasi epidemiologi lokal infeksi dan organisme penyebabnya. Semenjak adanya resistensi bakteri, terapi empiris dengan antibiotik spektrum yang lebih luas akan diperlukan. Distribusi sensitifitas dan strain resisten bervariasi antar negara, antar rumah sakit dan bahkan antar pelayanan dalam satu rumah sakit. Data surveillance lokal juga harus tersedia. ${ }^{3}$ Sampai saat ini penelitian pola sensitifitas bakteri dan penggunaan antibiotik pada anak yang dirawat di RSPI SS belum ada.

Tujuan penelitian ini adalah untuk mengetahui pola sensitifitas bakteri dan penggunaan antibiotik pada pasien anak yang dirawat di RSPI SS.

\section{Metode}

Penelitian deskriptif retrospektif dari status rekam medis pasien anak yang dirawat sesuai dengan kriteria inklusi. Kriteria inklusi adalah semua pasien nonbedah anak, umur 1 bulan sampai 15 tahun yang dirawat tahun 2010 dan 2011 dengan hasil kultur tumbuh bakteri. Kriteria eksklusi adalah pasien yang dirawat diruang PICU dan pasien yang dalam perawatannya didiagnosis sebagai pasien bedah. Data awal hasil kultur pasien anak tahun 2010 dan 2011 diambil dari laporan instalasi laboratorium. ${ }^{5}$ Selanjutnya, status rekam medis pasien dan data jumlah pasien anak dicari di Instalasi Rekam Medis. Didapat data pasien anak non-bedah yang dirawat selama tahun 2010 dan 2011, berjumlah 3094 orang, dan pasien yang dapat antibiotik tahun 2010 dan 2011 berjumlah 1256. Berdasarkan laporan instalasi laboratorium, permintaan kultur dari ruang rawat anak Melati tahun 2010 dan 2011 berjumlah 286 sampel, dan hasil kultur yang tumbuh bakteri 96 sampel. Status rekam medis yang ditemukan 60,8 orang tidak diikutsertakan dalam penelitian karena memenuhi kriteria eksklusi, terdiri dari 6 orang pernah dirawat diruang PICU, dan 2 orang pasien bedah. Hanya 52 orang yang menjadi subjek penelitian. Penghitungan proporsi bakteri terbanyak dan sensitifitasnya terhadap antibiotik dihitung dari hasil kultur dan uji sensitifitas yang ditemukan.

\section{Hasil}

Limapuluh dua subjek penelitian, terdiri dari 32 $(61,5 \%)$ laki-laki dan $20(38,5 \%)$ anak perempuan. Kelompok umur terbanyak ditemukan adalah bayi 1 bulan-<1 tahun 13 (25\%). Pada kelompok umur di bawah lima tahun (Balita) 30 (57,7\%), dan 22 (42,3\%) umur 5-15 tahun. Rerata umur pasien adalah 5 tahun dengan rentangan umur 1 bulan sampai 14 tahun. Dari

Tabel 1. Profil subjek penelitian

\begin{tabular}{lcc}
\hline Karakteristik & Jumlah & $\%$ \\
\hline Jenis kelamin & & \\
$\quad$ Laki-laki & 32 & 61,5 \\
$\quad$ Perempuan & 20 & 38,5 \\
Kelompok umur & & \\
1 bulan $-<1$ tahun & 13 & 25 \\
1 tahun $-<3$ tahun & 11 & 21,1 \\
3 tahun $-<5$ tahun & 6 & 11,5 \\
5 tahun $-<12$ tahun & 10 & 19,2 \\
12 tahun -14 tahun & 11 & 21,1 \\
Lama dirawat (hari) & & \\
$\leq 7$ & 37 & 71,2 \\
$>7$ & 15 & 28,8 \\
\hline
\end{tabular}


Tabel 2. Distribusi bakteri hasil kultur

\begin{tabular}{|c|c|c|c|c|c|c|c|c|}
\hline No & Bakteri & Darah & Tinja & Urin & Pus & Sputum & Swab tenggorok & Jumlah \\
\hline 1 & S typhi & 11 & - & - & - & - & - & 11 \\
\hline 2 & E coli & 1 & 1 & 7 & - & - & - & 9 \\
\hline 3 & S epidermidis & 5 & - & 2 & - & - & - & 7 \\
\hline 4 & Klebsiella & 1 & 3 & 1 & - & - & - & 5 \\
\hline 5 & Proteus & - & 3 & 1 & 1 & - & - & 5 \\
\hline 6 & $S$ aureus & - & - & - & 2 & - & 1 & 3 \\
\hline 7 & Vibrio cholera & - & 3 & - & - & - & - & 3 \\
\hline 8 & Pseudomonas & - & 1 & 2 & - & - & - & 3 \\
\hline 9 & Enterobakter cloaca & - & 1 & - & 1 & - & - & 2 \\
\hline $10-15$ & 6 bakteri lain & 1 & 2 & 1 & 1 & 1 & - & 6 \\
\hline Jumlah & & 19 & 14 & 14 & 5 & 1 & 1 & 54 \\
\hline
\end{tabular}

Tabel 3. Persentase sensitifitas 5 bakteri terbanyak terhadap antibiotik

\begin{tabular}{|c|c|c|c|c|c|c|c|c|c|c|c|c|c|}
\hline 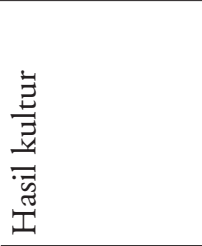 & 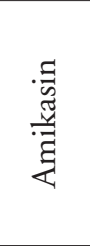 & 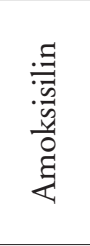 & 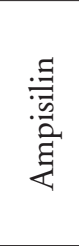 & 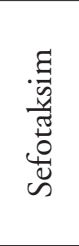 & 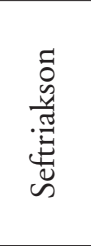 & 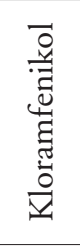 & 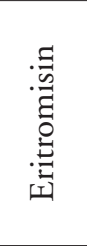 & 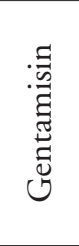 & 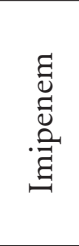 & 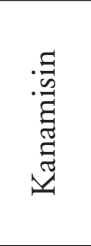 & 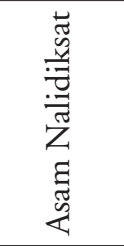 & 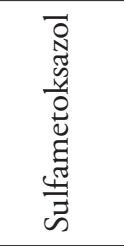 & 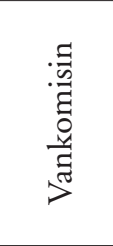 \\
\hline Styphi & 90.9 & 100 & 90.9 & 100 & 100 & 100 & 9.0 & 100 & 100 & 100 & 100 & 100 & (-) data \\
\hline E coli & 87,5 & 37,5 & 12,5 & 37,5 & 50 & 62,5 & 0 & 62,5 & 87,5 & 62,5 & 37,5 & 25 & (-) data \\
\hline S epidermidis & 100 & 85,7 & 42,9 & 71,4 & 42,9 & 57,1 & 42,9 & 85,7 & 85,7 & 42,9 & (-) data & (-) data & 71.4 \\
\hline $\mathrm{K}$ pnemonia & 100 & 0 & 0 & 20 & 20 & 20 & 0 & 80 & 100 & 20 & 80 & 20 & 20 \\
\hline Proteus & 100 & 60 & 40 & 100 & 100 & 20 & 0 & 100 & 100 & 80 & 40 & 20 & $(-)$ data \\
\hline
\end{tabular}

Sumber: Peta bakteri dan kepekaan terhadap antibiotik RSPI Sulianti Saroso ${ }^{5}$

52 subjek penelitian, yang dirawat $\leq 7$ hari $37(71,1 \%)$, dan yang dirawat $>7$ hari $15(28,9 \%)$. Rerata lama rawat pasien adalah 3.7 hari dengan rentangan lama rawat satu hari sampai 18 hari.

Dari 52 subjek penelitian, ditemukan hasil kultur tumbuh 54 bakteri pada 54 sampel, karena ada pasien yang diambil lebih dari satu sampel untuk dilakukan kultur. Dari 54 bakteri yang tumbuh didapat 15 jenis bakteri. Bakteri yang tumbuh terbanyak berasal dari darah $19(35,2 \%)$, tinja $14(25,9 \%)$, urin 14 $(25,9 \%)$, dan yang lainnya dari sputum, pus dan swab tenggorokan.

Bakteri terbanyak yang ditemukan adalah $S$. typhi 11 (20,4\%), E. coli 9 (16,7\%), dan S epidermidis $7(13 \%)$. Bakteri yang sedikit ditemukan ada 6 bakteri, masing-masing terdiri dari 1 bakteri, yaitu Acinetobacter baumani, Shigella equuli, Morganella morgagni, Salmonella enteritidis, Aeromonas hydrophila dan Basillus sp. Dari 54 hasil kultur, sebagian besar ditemukan adalah bakteri Gram negatif 46 (85,2\%) dan bakteri Gram positif 8 (14,8\%) terdiri dari $S$. epidermidis 7 dan basillus sp 1 . Semua $S$. typhi yang ditemukan berasal dari sampel darah. Sedangkan dari 9 E. coli, ditemukan 7 E. coli berasal dari sampel urin, satu dari sampel tinja, dan satu dari darah.

Dari 11 hasil kultur S. typhi yang ditemukan, didapat diagnosis dari status rekam medis 7 pasien dengan diagnosis demam tifoid, dua demam paratifoid, satu diagnosis meningitis tifosa, sedangkan 1 pasien didiagnosis sebagai suspek disentri amuba. Dari semua S. typhi yang ditemukan, didapat total 15 antibiotik, empat pasien mendapat lebih dari 1 antibiotik dalam waktu bersamaan. Antibiotik yang diberikan untuk 11 S. typhi, terdiri dari 6 kloramfenikol, 4 seftriakson, 3 sefotaksim, dan masing masing 1 kotrimolsazol, dan tiamfenikol. Pada uji sensitifitas, hasil kultur S. typhi terhadap antibiotik ditemukan sensitif $100 \%$ terhadap amoksisilin, sefotaksim, seftriakson, kloramfenikol, gentamisin, imipenem, kanamisin, asam nalidiksat, dan sulfametoksazol. Sedangkan terhadap amikasin 


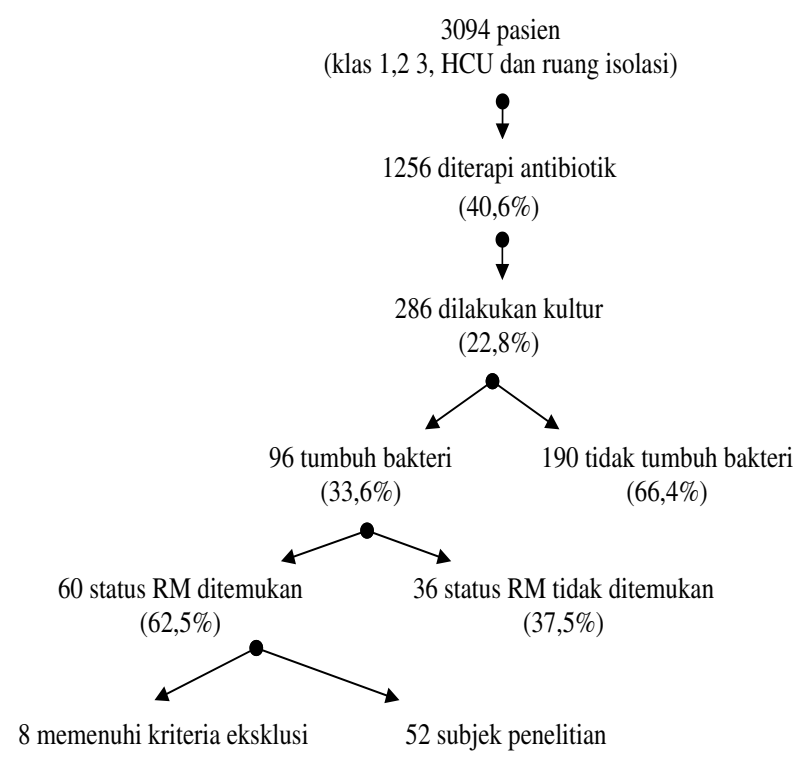

Gambar 1. Pemilihan subjek penelitian

dan ampisilin sensitifitasnya 90,9\%. Semua S. typhi sensitif $100 \%$ terhadap sefotaksim, seftriakson, kloramfenikol, kotrimoksazol, dan tidak ada data sensitifitas terhadap tiamfenikol.

Escherichia coli merupakan bakteri urutan kedua terbanyak setelah S. typhi. Ditemukan 9 antibiotik yang diberikan untuk terapi pasien terhadap penyakit yang disebabkan oleh $E$. coli, terdiri dari sefotaksim 3, kotrimoksazol 3, kloramfenikol 2, dan seftriakson 1. Dari hasil uji sensitifitas, E. coli sensitif $(87,5 \%)$ terhadap amikasin dan $(62,5 \%)$ terhadap kloramfenikol, gentamisin dan kanamisin, sedangkan terhadap antibiotik lainnya sensitifitasnya rendah, dibawah (60\%). Terlihat E. coli terhadap kloramfenikol sensitifitasnya baik $(62,5 \%)$, tetapi terhadap antibiotik lain yang digunakan seperti sefotaksim sensitifitasnya $(37,5 \%)$, terhadap seftriakson $(50 \%)$ dan terhadap kotrimoksazol sensitifitasnya hanya $25 \%$.

Staphylococcus epidermidis merupakan bakteri Gram positif terbanyak (7/8) yang ditemukan, dan merupakan urutan ketiga terbanyak hasil kultur, sesudah S. typhi dan E. coli. Sebagian besar (5/7) ditemukan dari sampel darah, dan 2 dari sampel urin. Dari uji sensitifitas hasilnya sangat baik terhadap amikasin (100\%), terhadap amoksisilin, gentamisin, dan imipenem sensitifitasnya masing-masing $(85,7 \%)$, terhadap sefotaksim dan vankomisin sensitifitasnya $(71,4 \%)$, tetapi terhadap antibiotik lain, sensitifitasnya tidak baik, kurang dari 60\%. Dari semua subjek penelitian, 51 orang sembuh dan pulang dari perawatan dengan perbaikan. Hasil uji invitro terlihat tidak selalu sama dengan invivo.

\section{Pembahasan}

Kelompok umur 1 bulan sampai kurang dibawah 1 tahun merupakan kelompok umur yang paling banyak ditemukan tumbuh bakteri, ini sama dengan hasil penelitian Satari $\mathrm{dkk}^{6}$ yang juga menemukan kelompok umur yang sama 1 bulan $-<1$ tahun yang terbanyak. Ini dimungkinkan karena kelompok umur ini mempunyai daya tahan tubuh yang lebih rendah dibandingkan dengan kelompok umur lainnya, sehingga mereka bisa menderita sakit lebih berat dibanding kelompok umur subjek lainnya.

Dari hasil kultur darah ditemukan 19 bakteri ditemukan tumbuh, sebagian besar 85,2\% adalah bakteri gram negatif, lebih kecil dibandingkan dengan penelitian Saderi $\mathrm{dkk}^{7}$ menemukan sebagian besar bakteri yang ditemukan dari kultur darah anak di rumah sakit universitas di Taheran, Iran, adalah Gram negatif $(93,1 \%)$. Subjek penelitian adalah dari sampel darah pasien anak dengan dugaan sepsis.

Bakteri terbanyak ditemukan adalah S. typhi $(20,4 \%)$ dan semuanya ditemukan dari darah. Escherichia coli (16,7\%) ditemukan terbanyak setelah S. typhi. Hasil penelitian yang sama dilaporkan oleh Shwe $\mathrm{dkk}^{8}$ yang menemukan $S$ typhi $(43,1 \%)$ dan $E$. coli $(12,3 \%)$ merupakan bakteri terbanyak dari kultur darah. Dari status rekam medis didapat diagnosis 11 hasil kultur $S$ typhi, 7 pasien demam tifoid, dua demam paratifoid, satu diagnosis meningitis tifosa, sedangkan 1 pasien didiagnosis sebagai suspek disentri amuba. Antibiotik yang diberikan untuk $S$. typhi sensitifitasnya sangat baik terhadap kotrimoksazol, kloramfenikol, sefotaksim, dan seftriakson, masing-masing 100\%. Sedangkan terhadap tiamfenikol tidak tersedia data tentang hasil uji sensitifitasnya.

Hasil tersebut berbeda dengan penelitian Shwe $\mathrm{dkk}^{8}$ yang menemukan $S$ typhi terbanyak dari kultur darah, tetapi resisten terhadap antibiotik konvensional, seperti ampisilin, amoksisilin, kloramfenikol, dan kotrimoksazol. Hal tersebut bisa ditimbulkan karena perbedaan subjek penelitian dan kebijakan penggunaan antibiotik yang berlaku ditempat masing-masing

Escherichia coli adalah bakteri nomor 2 terbanyak dari 
hasil kultur, dan sebagian besar ditemukan dari urin, darah dan tinja. Escherichia coli dalam urin menyebabkan infeksi saluran kencing (ISK). Dari 6 E. coli yang ditemukan dari urin, semuanya didiagnosis sebagai ISK, satu $E$ coli dari darah ditemukan dengan diagnosis ISPA dan satu $E$. coli dari tinja ditemukan dengan diagnosis gastro enteritis dehidrasi berat (GED berat).

Ditemukan 9 antibiotik yang diberikan untuk terapi penyakit yang disebabkan oleh bakteri $E$. coli, terdiri dari sefotaksim 3, kotrimoksazol 3, kloramfenikol 2, dan seftriakson 1. Dari hasil uji sensitifitas, E. coli sensitif 87,5\% terhadap amoksisilin dan gentamisin, dan $62,5 \%$ terhadap kloramfenikol, gentamisin dan kanamisin, sedangkan terhadap antibiotik lainnya sensitifitasnya dibawah $60 \%$. Terlihat penggunaan kloramfenikol sensitifitasnya baik $(62,5 \%)$, tetapi terhadap sefotaksim sensitifitasnya $37,5 \%$, terhadap seftriakson $50 \%$ dan terhadap kotrimoksazol sensitifitasnya hanya $25 \%$.

Staphylococcus epidermidis merupakan bakteri terbanyak ke-3 dari hasil kultur, sebagian besar ditemukan dari sampel darah. Staphylococcus epidermidis adalah kokus Gram positif dan koagulase negatif, merupakan flora normal pada kulit dan mukosa manusia. Staphylococcus epidermidis merupakan penyebab infeksi nosokomial paling umum pada penggunaan biomaterial dalam lingkungan klinis. Infeksi S. epidermidis dapat terjadi karena bakteri ini menghasilkan lendir yang membentuk biofilm hidrofobik pada alat-alat medis di rumah sakit. Biofilm tersebut sebagai penghalang difusi terhadap antibiotik sehingga pengobatan dengan antibiotik sering tidak efektif. Biasanya, resisten terhadap antibiotik yang biasa digunakan sehingga vankomisin atau rifampisin digunakan untuk infeksi S. epidermidis ini. ${ }^{10}$ Semua subjek penelitian pulang dengan perbaikan dengan pengobatan yang biasa diberikan, kemungkinan telah terjadi kontaminasi pada sampel darah. Untuk mengurangi terjadinya kontaminasi adalah dengan menerapkan teknik aseptik dan memasyarakatkan kebiasaan mencuci tangan dengan benar.

\section{Kesimpulan}

Bakteri terbanyak ditemukan dari hasil kultur pasien anak yang dirawat di RSPI Sulianti Saroso adalah $S$. typhi (20,4\%) dan E. coli (16.7\%). Salmonella typhi sensitif $100 \%$ terhadap kloramfenikol, kotrimoksazol, sefotaksim, dan seftriakson yang digunakan. Penggunaannya masih bisa dengan lini pertama sejauh tidak ada kontra indikasi. Penggunaan antibiotik untuk terapi penyakit yang kemungkinan penyebabnya $E$. coli harus ditinjau kembali karena sensitifitas penggunaan terhadap sefotaksim (37,5\%), seftriakson (50\%), dan kotrimoksazol hanya (25\%). Masih diperlukan penelitian selanjutnya secara periodik.

\section{Daftar pustaka}

1. Sujith J.Chandy. Consequenses of irrational use of Antibiotics. Indian J Med Ethics 2012;4:1-2.

2. Radyowijati A, Hilbrand Haak. Improving antibiotic use in low-income countries: An overview of evidence on determinants.Soc.Sci Med 2003;57:733-44.

3. Gyssen IC. Audits for monitoring the quality of Antimicrobial prescription. Dalam: Van der Meer JW, Gould IM, penyunting. Antibiotic policies theory and practice. New York: Kluwer Academic;2005.h.197-226.

4. Tri Ika KN. Evaluasi penggunaan antibiotik berdasar kriteia Gyssens pasien rawat inap kelas III dibagian Ilmu Penyakit Dalam RSUP Dr Kariadi Periode AgustusDesember 2008. Semarang: Karya Tulis Ilmiah FDOK UNDIP, 2009.

5. Sirait MS. Peta bakteri dan kepekaan terhadap antibiotik RSPI Sulianti Saroso tahun 2010 dan 2011.

6. Satari HI, Firmansyah A, Theresia. Qualitative evaluation of antibiotic usage in pediatric patients. Paediatrica Indonesiana 2011;51:303-9.

7. Saderi H, Loni M, Karimi A. Frequency of bacteria isolated from childrens blood culture in University Hospital in Iran and their antibiotic susceptibility pattern. Disampaikan pada 30th Annual Meeting of the ESPID, Thessaloniki, Greece.2012.

8. Shwe TN,Nyein MM, Yi W, Mon A. Blood culture isolates from children admitted to Medical Unit III, Yangon Childrens Hospital. Southeast Asian J Trop Med Pub Health 2003;33:764-71.

9. James PN, James KP. Diarrheagenic Escherichia Coli. Clin Microbiol Rev 1998;11:142-201

10. Parija SC. Bacteriology in textbook of microbiology and immunology. Amsterdam: Elsevier Health Sciences 2009.h.260-91. 